\title{
Berszán István
}

\section{Textuality - a New Stereotype of Comparative Literature}

The paper first indicates the situation of comparative literature among the other disciplines as an attempt to unfold it as a result of previous proceedings on hermeneutics and discourse analyses. But after the 'invocation' of some recent theoretical statements the argumentation turns into a critique of some basic concepts of the field, such as "formation discursive", textuality or retoricity by sketching out an alternative way of research, which prefers following instead of creating relations, stresses urging instead of rules and yields an art of practicing instead of an archeology of the knowledge. Beyond its attempt to unmask the stereotypes of the questioned research practice the paper offers a narration of some experimental exercises.

\section{A komparatisztika egy új keletú sztereotípiája - a textualitás}

A sztereotípia fogalmának bevonása az összehasonlító irodalmi kutatás egy lehetséges témamegjelölésébe azt jelzi, hogy az archetipológiák által megalapozott komparatisztikai vizsgálat, mint például a Northrop Frye-é vagy a Gilbert Durand-é, legalábbis letünőben van. A mítoszok stilizált mintáinak közlésegységekként vagy grammatikai szabályrendszerként felfogott müködése, illetöleg a kompenzáló képzelet struktúrái, melyek a szimbólumok motivációi között bejárható antropológiai trasszék mentén térképezhetők fel - egyre inkább átkerülnek az analízis technikáinak pozíciójából az analízis tárgyának pozíciójába. Ezt a váltást - ahogyan nekem tünik fel - három fö kutatási gyakorlat munkálja: az egyik az archetipológiákba rendezett hagyomány recepciótörténeténeti elmozdulásának hermeneutikája, a másik a beszédképződmények Curtiusig visszanyúló analízise, melyet Foucault az egész nyugati tudás archeológiájává fejlesztett, Derrida és Paul de Man pedig az írás, illetve retoricitás meghaladhatatlan mozgásterének elméletévé; a harmadik irányt a mindinkább feltörekvő kognitív tudományok képezik a posztstrukturalizmus óta eluralkodó filozófiai diskurzus ellensúlyozására tett kísérleteikben, melyek a legújabb csúcstudományok (agyfiziológia, génsebészet) felfedezéseit hasznosítják az eddig csak elnagyoltan vázolt kognitív folyamatok precízebb nyomon követése során.

A kulturális változóktól független archetípusok helyébe, melyek minden későbbi fejlemény eredeteként tüntek fel, ezekben az analízisekben olyan történeti képződmények kerülnek elötérbe, melyeket immár nem deduktíve magyarázunk, hanem azoknak a diszkurzív szabályoknak és választásoknak a mezejét elemezve, melyek korábbi szabályoktól és választásoktól elhatárolódva éppen ezekhez a képződményekhez vezettek. Azoknak a feltételeknek a kutatása vált fontossá, amelyek az egymástól elkülönböződő viszonynyalábok váltakozását, sorrendjét, kapcsolatait teszik lehetővé. A sztereotípiákra irányuló komparatisztikai vizsgálatnak várhatóan ugyancsak a hagyományteremtődés, a diskurzus, illetve a kognitív folyamat képződményeinek ezeket a képzési szabályait kell faggatnia: valamely irodalmi vagy kritikai beszédmód tárgyainak, kijelentésformáinak, leggyakrabban visszatérő fogalmainak, illetve más diskurzusok szituációiba kerülő sémáinak, teorémáinak viselkedésrendjét. A sztereotípiák mint beszédképződmények ugyanis nyilvánvalóan nem ugyanazon szintűek még akkor sem, ha elkoptatottságuk, rutinszerüségük alapján gyakran önálló halmazként különítjük el őket. Különbség van például a pasztorális költészet kötelezően elöírt idilli szcenikája és ennek megszokott klasszicizáló vagy szentimentális formulái között, és egészen másfajta különbség, mondjuk az ember antropológiai fogalma és a lírai alany diskurzusban elfoglalt 
központi pozíciójának elve között. A sztereotípiákat már csak azért sem szükíthetjük le a tematikus közhelyek körére, mert a téma maga sem valamely eleve adott, beszéden kívüli terület, hanem bizonyos képzési szabályok, illetve a diskurzus keretén belül nyitott lehetőségek közüli sztereotip választások eredménye.

Hogyha megmaradunk az elkoptatottság valamiképpen meghatározó mozzanatánál, könnyen igazolhatjuk a sztereotípiák beszédképződmény jellegét. Egy elkoptatott séma magától értetődő ugyan, de ugyanakkor semmitmondóan üres is. Vajon mit érthetünk meg abból, aminek nincs semmi értelme? Csak azt, hogy valamely, még érvényes fórum által régóta és biztosan elfogadott képződménnyel van dolgunk, valamivel, amit tudni illik. Még ha fel is merül az értelmével kapcsolatos kétely, azt rögtön elnyomja a beszélőben önkéntelenül feltoluló érv, hogy ha ő nem is, de a többiek biztosan értik, hiszen „ezt mindenki így szokta mondani”. A sztereotípia ilyenformán olyasvalami, ami nyilvánvalóan mondható, de nem érdekes. Csak attól válik érdekessé - pl. egy elöadás kijelölt tárgyaként -, ha arra kérdezünk rá, hogy miért éppen ez az, ami nyilvánvalóan mondható, és hogy miért nem nyilvánvaló az, hogy miért nyilvánvaló.

Ezt a kérdésfelvetést - a kortárs elméleti diskurzusban mondhatni sztereotip logikai bukfencen túlmenően - súlyosan elbonyolíthatja az a fordulat, ha megpróbálunk a textualitás sztereotipiájáról beszélni. Manapság ugyanis ez az, ami biztosan nem mondható. Utána fogunk járni, hogy miért nem (és hogy miért igen mégis), de előbb - minthogy ezen a ponton már megtehetem - hadd fogalmazzam meg a munkahipotézisem: valamely diskurzus képzési szabályainak azok a legmeghatározóbb sztereotípiái, amelyek nyilvánvalóan nem mondhatók.

Hogyha a sztereotípiát beszédképződményként határozzuk meg, akkor ezzel azt állítjuk, hogy létrejöttének tere a textualitás: elemek szóródásának, illetve a viszonylétesülésnek az a játéka, melyet nem foglalhatunk végérvényes képletekbe, mindenütt eligazító ősi typosokba. A textualitás maga tehát soha nem válhat ilyen értelemben képződménnyé, mert sohasem adott önmagában és a maga teljességében. Legfeljebb másodlagosan adódhat egy olyan diskurzus ürügyén, amely a textualitást teszi meg tárgyául. Nem szabad tehát összekevernünk a textualitás témáját a textualitás játékával.

De vajon megoldottuk-e ezzel a különbségtétellel a felvetett problémát? Nem kellene-e felülvizsgálni a sztereotípia tisztán beszédképződmény jellegét? Nem mentettük-e át a typosok időn kívüli, egyetemes jellegét a képződmény textuális történetének egyetlen, kizárólagos idejébe? Erre vall az, hogy tudniillik az összehasonlító irodalom éppen (és csakis) szövegeket hasonlít össze. Ugye ez annyira magától értetődő, hogy nem is lehet komolyan venni esetleges megkérdőjelezését? Hiszen legelemibb, legnyilvánvalóbb szintjén az irodalom szövegek halmazaiként adódik. Maga a literatúra szó is - melynek használata messze megelözi a textualitás kortárs elméleteit - eleve a jelölök kétségbevonhatatlan materialitására irányítja a figyelmünket. A szóba jöhető eszméknek, tárgyaknak, szubjektumoknak pedig, melyeket sokáig a szöveget megelőzőnek véltek, éppen az irodalmi fikció leplezi le a szövegszerüségét. Mégis megfontolandónak tartom, hogy miért kapaszkodunk az írás és olvasás gyakorlatának vizsgálatakor a betű textuális materialitásába. Miért választjuk ki például a könyv megszerzésének (felkutatásának, megpillantásának, tulajdonná tevésének), a felnyitása előtti frenetikus várakozásnak (a hazafelé szállításának, esetleges kényszerü félretevésének, szemmel tartásának vagy gyakori emlékezetbe idézésének), az olvasóhely kiválasztásának, a táblák felnyitásának, a lapozásnak, az olvasás közben felvett és átváltott pózoknak, a lélegzés ritmusváltásainak, a csalódásnak, a megkönnyebülésnek, az olvasmány szeretésének, röviden az olvasás közbeni impulzus- és tartamkeresésnek ${ }^{354}$ a történései közül

${ }^{354}$ Lásd Italo CALVINO: Ha egy téli éjszakán egy utazó (ford. Telegdi Polgár István, Európa, Budapest, 1985) c. regényének I. fejezetét. 
egyedül az értelmezési folyamat textuális aktivitását? Hiszen emezek moccanásai is legalább annyira „materiálisak”, mint a literatúra betüje, valamennyien ugyanolyan tagadhatatlan tartozékai az olvasásnak, mint a szövegek halmazai. Nem volna tanácsos mindezeket járulékos, esetleg egyenesen nem irodalmi körülményeknek nyilvánítani, hiszen az csorbítaná a textualitás hatáskörét. Ugyanakkor textualizálásuk is minden bizonnyal kockázatos vállalkozás. Hogy ma mégis, mindenáron megkísérelendő ez a kiterjesztés, az leginkább annak folyománya, hogy az összehasonlítás maga, még a komparatisztika nem irodalmi (képzöművészeti, zenei, etnográfiai) ágazataiban is: szigorúan textuális.

Nem egyszerüen azokról a nyelvészeti, illetve poétikai metaforákról van szó, amelyekkel a képek, hangzások, rítusok alakzatait leírjuk, hanem mindenekelőtt arról az elméleti-stratégiai döntésről, melynek következtében összehasonlítani annyit tesz, mint viszonyba helyezni. Ennek a - megint csak magától értetődőnek tűnő - választásnak köszönhetően a kapcsolatok csakis a másikhoz viszonyitott távolságteremtésként, vagyis artikulációs gesztusként jöhetnek számításba. Úgy tünhet, hogy az összehasonlításnak szükséges velejárója az elkülönítés, pedig a különbség nem minden kapcsolat feltétele, hanem csak a viszonylétesítésé. Az olvasó calvinói frenetikus várakozása kapcsolatban van az olvasmánnyal, de nem artikulálódik köztük semmiféle viszony. A várakozás például nem előzi meg az olvasmányt, hiszen a már elolvasottak mindenkori folytatásához is kapcsolódik. Az sem tartható, hogy a várakozás értelmezné az olvasmányt, hiszen amennyiben valóban frenetikus, úgy nem valami értelemre irányuló heurisztikus folyamat funkciója (pl. elvárási horizont), hanem készséges elébemenetel a feltételezhetetlennek: nincs az az értelmezés, amely a várakozó olvasó számára helyettesíteni tudná az olvasmány következő passzusát. A textuális összehasonlítás kivonja magát az olvasmány várakozásra késztető parancsai alól, így aztán - „érintettség” híján - csak szabályokat tár fel, melyek viszonyokat jelölnek egymás lehetséges allegóriáiként kapcsolódó struktúrák között. A textualitásnak ez a sztereotípiája, amely - az összehasonlítandó szövegeket is beleértve - minden „képződményt” viszonyok hálójában ragad meg, a viszonylétesítés nyugati gyakorlatának immár alighanem teljesen átlátszóvá, s így szinte észrevehetetlenné koptatott szokása.

A tudás archeológiájában Foucault ${ }^{355}$ a kijelentés (énonciation) sajátos funkciójáról beszél, amely abban különbözik a nyelvtani mondatétól vagy a logikai propozícióétól, hogy azok létesülésének feltételeként működik. Az archeológiai leírás kései feltünéséig ez a funkció azért maradhatott láthatatlan, mert ,ama túlságosan is ismerős dolgok közé tartozik, amelyeket szüntelenül szem elől tévesztünk” (143.), mert „egyszerre nem látható és nem elrejtett" (141.). A kijelentés ugyanis, noha jelek egy-egy ténylegesen létrejött halmazának létezési módját képezi, sohasem tünik fel úgy, mint a mondatok, propozíciók, kifejezések melletti újabb egység, hanem az ilyen jellegü egységekben müködik. Így aztán a nyelv minden elemzése feltételezi anélkül, hogy valaha is napvilágra kellene hozniuk. Foucault figyelmeztet, hogy a kijelentések területét csak ,névtelen mezőként” szabad leírnunk, hogy ne vonatkoztassuk azt semmiféle tudatszerü, kollektív vagy transzcendens szubjektivitásra. Vajon ez az elővigyázatosság nem cinkosa annak, ami biztosan nem mondható - még az archeológiai diskurzusban sem? Hiszen amíg a kijelentés funkciójának nincs semmilyen néven nevezendö alanya, addig minden lehetséges alanyi pozíció megképződésének és eloszlásának egyedüli felségterülete maradhat. De ki az akkor mégis, aki parancsolatban tiltja a diskurzus szabályainak áthágását? - ekképpen: „Nem szabad többé a kijelentéseket valamiféle szuverén szubjektivitásra vonatkoztatva elhelyezni, hanem a kijelentési mezöre jellemző hatásokat kell felismerni a beszélő szubjektivitás különféle formáiban.” (158.) Melyik az az alanyi pozíció ebben a mondatban, amely „egyszerre nem látható és nem

\footnotetext{
${ }^{355}$ Michel FOUCAULT: A tudás archeológiája. Atlantisz, Budapest, 2001.
} 
elrejtett"? Éppenséggel a beszélő szubjektivitásé, akire a tiltás korlátozódik (a szó minden értelmében).

Leginkább szokásai teszik a szubjektumot. Azok a gyakorlatok, amelyeket a hozzá hasonlóan cselekvő szubjektumokkal együtt szokott gyakorolni, illetve az, ahogyan ő szokta gyakorolni azokat. Hogyha azonban a szokásai teszik is a szubjektumot, miközben a szubjektum teszi a szokásait, ez a kölcsönösség nem föltétlenül jelenti azt, hogy egymást képezik. A képzési szabályok csak a diszkurzív gyakorlatokban érvényesek, azokban, amelyeket a beszélő szubjektum szokott gyakorolni. Sajnos, a beszélöknek olykor rossz szokásaik is vannak, például túl sokat beszélnek, avagy akkor is beszélnek, amikor jobban tennék, ha hallgatnának. Az archeológiai leírás néha érezhetően enged annak a kísértésnek, hogy minden gyakorlatot a diszkurzív gyakorlat változataként tételezzen. Még rosszabb, ha valaki a diszkurzív gyakorlat szabályaihoz igazítva próbálja meg gyakorolni a nem diszkurzív gyakorlatokat: viszonyokat tisztáz, amikor odaadóan figyelnie kellene valamely impulzusra, vagy szövegek vizsgálatára korlátozza a komparatisztikát. Nem arról van szó, hogy másfajta szabályokhoz kellene igazodnia, hanem arról, hogy megtanuljon követni olyan parancsokat/késztetéseket is, amelyek nem szabályok: nem vonnak valamely viszonyhálóba, hogy viszonyulásra kényszerítsenek, hanem másféle gyakorlatokba kapcsolnak be olyan gesztusokra ösztönözve, melyek eltávolító viszonylétesítés helyett az illető ritmus tartamában tartanak. Az összehasonlítás ilyenkor inkább hasonulás: a viselkedés minél fokozottabb ráhangolása az összehasonlítandókra. Különbségtevés helyett annak megtanulása, hogyan váltsunk át egyik gyakorlatból a másikba. A választás ezúttal nem a diszkurzív gyakorlaton belüli döntésfunkció, hanem a döntéshozatalnak időbeli tájékozódásként történése. Tájékozódni az időben annyit tesz, mint tudni azt, hogy mikor minek van az ideje. A tudás leíró archeológiájához képest ez inkább a tudás gyakorló müvészete: az írni tudásé és az olvasni tudásé például, melyben az archívum diszkurzív történetisége más-más ritmusú időkké változik, olyan történésekké, ahol már nem viszonyok képezik, hanem ráhangolódások, rezonanciák gerjesztik a kapcsolatokat.

Természetesen, egy ilyen komparatisztikához nem elég a beszéd. Nem lehet például egy hagyományos konferencián müvelni, sem pedig analitikus tanulmányokban: olyan gyakorlatokra van szükség, amelyek megváltoztatják a kutatási és az olvasási szokásainkat.

Ahogy Foucault archeológiájában sem föltétlenül a beszéd szentesített egységei (mondat, könyv, mü) képezték a kijelentések vizsgálatának kiinduló alapját, az írás- és olvasásgyakorlatok sem föltétlenül felolvasott vagy nyomtatott szövegekhez kapcsolódnak. A kijelentések mezeje mellett körös-körül más területeket is fel kell tárnunk, ahová látható és nem látható gesztusaink kalauzolnak el. Így azután a papírra írt olvasmányokban is megtanulhatunk majd utánaindulni a nem szabály jellegü késztetéseknek. Ez a tanulás a szó minden értelmében $t o ̈ b b$ időt igényel, itt csak ízelítésképpen mutatok be néhány gyakorlatot.

\section{Maradj a cipőidben}

Megálltam egy fa alatt, és ágai közt az égre néztem: a kékség benyúlt az ágak közt, s végtelen tapintattal körülfogott pár levelet. Kiléptem a cipőmből, s valamivel odébb menve visszafordultam. Láttam, hogy már nem vagyok ott a fa alatt: egyszerűen üresek a cipőim. Megdöbbentett a pillanat kibeszélhetetlen kincse. És a veszteség. Igyekeztem vissza a cipőimbe, hogy amíg a fa alatt vagyok, ott is maradjak.

Avagy fogj egy jó könyvet, ülj ki egy bokor árnyékába, s olvass el figyelmesen egy rövid passzust. Azután tedd le a könyvet a füre, gyere el néhány lépést, és nézd meg, hogy nem vagy a bokornál, hogy csak a szél forgatja a lapokat. Ez segíteni fog abban, hogy megtanulj vigyázni az olvasás idejére. 


\section{Hagyd, hogy tartson}

Jó ideje volt már, hogy a csillagfénynél elveszítettem délutáni nyomaimat. A hó majdnem térdig ért a szálas fenyvesben, $\mathrm{s}$ tudtam, hogy ha sehol nem véteném is el az irányt, legalább két óra kell még az erdőkitermelő útig, ahol az autót hagytam. Féltem. S nem segítettek a magamban ismételgetett biztatások. Akkor elkezdtem figyelni arra, amitől menekülni akartam: a fák között besürüsödő sötétre, a talpam alá gyürődő vastag hódunyhára, szélhimbálta törzsek nyikorgásaira és a lábaimban felgyülő fáradtság-gócokra. Láttam az árnyak testetlen bársonyát, az éjben is csillogó hókristályokat, a fenyőtörzsek megadó kitartását és már sokszor kipróbált lábaim egyenletes ritmusát. Egyre barátságosabbakká lettek iménti ellenségeim. A legsürübb oldalban hirtelen elöntött valami átható, szinte tapintható otthonosság. Így érezheti magát egy szarvas a rejtekén.

Ha nem szoktál éjszaka a hegyekben járni, keress egy sötét kertet vagy sikátort. Nem baj, ha félsz, csak a félelmedtöl ne félj: engedd magad félni. Ne igyekezz rögtön megszüntetni a borzongást, figyelj kitartóan a borzongatóra.

\section{Összehasonlító olvasótúra}

A rituális írás és olvasás műhely résztvevőit aznap olvasótúrára vittem. Szerettem volna úgy olvasni velük, ahogy gyerekkoromban barátaimmal az indiánkönyveket. Kölcsön adtuk egymásnak a Winetout, a Hosszú Tollat meg Az ezüst tó kincsét, s közben indiánoztunk. Építettünk egy kunyhót az erdőben, lándzsákat meg íjakat készítettünk, s megtanultunk kést és fejszét dobálni a fatörzsekbe. Gáttal duzzasztottuk fel a folyót és tutajt eszkábáltunk, mellyel nemcsak hosszú vízi utakat tehettünk, hanem kitünően lehetett halászni meg fejest ugorni is róla. A kutyámat is bevettük az indiáncsapatba: tudott magas partról vízbe ugrani, biztatásra kitartóan kaparta a földet (a folyóparti iszapba egyszer akkora lyukat ásattunk vele, hogy egészen belefért), fára mászott, kergetőztünk és bújócskáztunk vele az erdőben. Nevetni is tudott.

Nem úgy indiánoztunk, hogy megpróbáltuk eljátszani az olvasott jelenteket, sokkal hüségesebbek voltunk a könyveinkhez: hagytuk a történetüket velünk folytatódni.

Erről meséltem valamit a mühelyemhez csatlakozóknak, majd hátizsákunkban a mindennapi kenyérrel és a mindennapi olvasnivalóval libasorban kivonultunk a táborból. Elözőleg figyelmezettem őket, hogy nem fogunk beszélni arról, amit olvasunk. Mivel az egyetemen néha előfordul, hogy olyan könyvekröl is beszélünk, amelyeket nem olvastunk, ezt itt azzal ellensúlyozzuk, hogy elolvasunk valamit, és nem beszélünk róla. Most csak az a fontos, ahogyan olvasunk.

De hogyan olvassunk? - szegezték nekem. Elmondtam hát nekik, hogyan lestünk apámmal a vadakra.

Soha nem volt fegyverünk. Egy szeptember végi éjszakán szarvasetetőben aludtunk. Nem nyomott el azonnal az álom, mert körös-körül meg-megzendült az erdő a bikák baritonjától, s az az izgalom is ébren tartott, mellyel a hajnali lesre vártunk, amikor talán láthatjuk is majd őket. Egyszer ágreccsenés hallatszott az erdőből. Kisvártatva újabb reccsenések. „Lopakodjunk közelebb” - súgtam apámnak -, s már akartam is leereszkedni az etetőből. Keze a vállamra nehezedett: „Várunk.” Az etetőt apró tisztás vette körül, néhány lépésre egy régen levágott fenyő tőkéje derengett a holdfényben. Ott bukkant ki a vezérgőlye az erdőből, majd egy kisebb konda a nyomában. A kivájt fenyőtőkében gyakran volt só a szarvasoknak. Ilyenkor az eső sóoldattal itatta át a korhadó fát, úgyhogy az akkor is sós maradt, ha már nem voltak benne sódarabok. A vaddisznók egymást oldalba bökve, vinnyogva igyekeztek közel férkőzni a tőkéhez, s jól hallatszott, amint agyaraikkal ki-kitörnek egy-egy darabot belöle. 
Nem moccantunk. A konda turkálni kezdett körülöttünk. Úgy látszik, a kedvező széljárás s az a magasság, amellyel a szénával tömött szarvasetetö fölöttük tartott, elég volt ahhoz, hogy ne orrintsanak meg azonnal. Az egyik fiatal kan egészen közel jött, már nem is láttuk a szénától. Hirtelen remegni kezdett az egész etető, s hallatszott, ahogy sörtéi súrlódnak az egyik tartóoszlopon. Csámcsogott, aprókat röffentett elégedetten, aztán követte a tisztásról tovább húzódó kondát, le a tejjel és mézzel folyó mezők irányába.

Így próbáltunk meg olvasni is: leshelyünkön vártuk, hogy ránk találjanak a késztetések, és a világért sem akartuk őket semmivel elijeszteni.

Háromszor álltunk meg ebédig: hol egy patak köveire ültünk, hol egy szellő járta dombra, hol meg a tábortűz köré. Csobogott a víz, csiviteltek a madarak, fütyörészett egy juhász, pattogott a tüz. Mindannyian ugyanarra az olvasmányra lestünk. Azután egyenként felolvastunk belöle egy-egy - mondatnál legtöbbször rövidebb - passzust: azt, amelyik a leshelyünkhöz dörgölözött. Ebéd után visszafordultunk, s ugyanazokon a helyeken ültünk le olvasni, mint arra menet.

Mikor néhányan további útmutatást kértek, vettem a rövid nyelü fejszét és először egy, majd két pördülésnyi távolságról beledobtam egy fenyő törzsébe. Éppen úgy, mint indiánkoromban. Azután sorra mindenkinek odaadtam, hogy próbálkozzanak. Tanulják meg, hogyan pördül a fejsze, miként kell felemelni, nekilendíteni és mekkora erővel. Nem úgy figyeltünk a fejszedobásra, mintha később mondani akarnánk valamit róla, hanem úgy, hogy begyakoroljuk a gesztust. Lassan már a többiek próbálkozásait is az izomtónusainkkal követtük. Utána már sokkal jobban tudtunk olvasni is.

Abba a völgybe, ahol jó darabon az úton folyt a patak, visszafele jövet betüzött az alkonyi nap. Tükröződő vörös fényben ugráltunk a vízből kiálló köveken. Olyan volt, mint egy balett. Mint az együttolvasás. 